\title{
Britain and the beginning of Scotland
}

\author{
Sir John Rhŷs Memorial Lecture \\ Read 5 December 2013 \\ DAUVIT BROUN
}

\begin{abstract}
A British dimension is crucial for understanding the earliest stage in the emergence in the late 12th century of an idea of Scotland, in its most basic sense, as the country we recognise today. It is also lies at the heart of the origins of the earliest idea of Scotland that can be detected: the notion of Scotland as the country north of the Forth, an idea that can be traced back to the Picts. In both cases, the overriding concern was to accentuate Scotland's separateness from the south. Being British may be an essential element of any explanation of Scotland's beginnings, but only in a way that suggests that Scotland's place in Britain has from the beginning been inherently uneasy.
\end{abstract}

Keywords: Cinaed mac Ailpín, charters, royal/baronial justice, Henry II, Alba, Britons, Forth, Pictish symbols, Pictish king-list.

Until recently it was generally held that Scotland first began to take shape with a union of Picts and Scots under Cinaed mac Ailpín, who died in 858. For example, Edward James in his Britain in the First Millennium, published in 2001, describes how 'a king of Dál Riata, Cinaed mac Ailpín (Kenneth mac Alpine), definitively united the Picts and the Scots into a new kingdom', so that 'in the middle of the ninth century the kingdom of Scotland is unified, under Cinaed mac Ailpín (840/2-858), a Gaelic rather than a Pictish king. ${ }^{1}$ Cinaed was the common ancestor in the male line of kings of Scots from around 890 until 1034. This alone could explain how he came to be regarded in the 10th century as one of the kingdom's founding figures. ${ }^{2}$ If so, he would only have gained this status retrospectively. Be this as it may, there is no longer a

${ }^{1}$ James (2001: 138, 230). Similarly Barrell (2000: 3), who talks of the 'sudden overthrow' of the Picts by Cinaed.

${ }^{2}$ Broun (1999a: 170-4). 
consensus about his role, or about whether he was a Gael or a Pict. ${ }^{3}$ Some have abandoned the notion of Cinaed as founder but have still retained the idea that a new, united kingdom emerged in the end of the 9th century - 'a homologated kingship of Picts and Scots', to quote Archie Duncan in $2002 .{ }^{4}$ The only point that is not disputed is that by the 10th century the inhabitants of what had been the Pictish kingdom spoke Gaelic rather than Pictish. Cinaed mac Ailpín, however, is no longer regarded generally as the principal agent of this fundamental change. ${ }^{5}$

The idea that a new entity, a united kingdom, was formed-rather than an expanded Gaelic realm or the Pictish kingdom 'under new management', as it wereis centuries later than the 9th century. In John of Fordun's Chronica Gentis Scottorum of the mid-1380s, we are told that, "with the consent of God it came about that [Cinaed mac Ailpín], the first of all the kings to take over the whole northern area of Albion as sole ruler [i.e. Scotland north of the Forth], successfully formed one kingdom out of two'. ${ }^{6}$ It is also claimed (in the same passage) that Cinaed himself 'compiled the laws which are called the laws of mac Ailpín ... some of which remain and are current among the peoples [of the kingdom]'. ${ }^{7}$ Cinaed previously had appeared simply as the Scottish king who destroyed the Picts. ${ }^{8}$ Here he was portrayed as architect of a new realm.

This treatment of Cinaed was probably older than Fordun by a little over a century. There are reasonable grounds to suppose that Fordun here was merely following the earliest detectable continuous narrative of Scottish history written probably in the 1260s by the Frenchman Richard Vairement: Vairement came to Scotland with Alexander II's queen, Marie de Couci, in 1239. ${ }^{9}$ An earlier attempt to present Scotland as a merger of two kingdoms is in a king-list in which kings of Scots from Cinaed onwards are portrayed as the successors of both a long series of Pictish kings and a list of reges Scottorum. ${ }^{10}$ This was one of Vairement's sources, and can be dated to the reign of Alexander II (1214-1249). Cinaed's role as lawgiver may also be a little older than Vairement's history. The 'laws of mac Ailpín' are mentioned in an addition to the

\footnotetext{
${ }^{3}$ Broun (2005: 264-6); Clancy (2010: 358-62); Dumville (1997: 35-6); Herbert (2000); Charles-Edwards (2008); Woolf (2007: 93-8).

${ }^{4}$ Duncan (2002: 15).

${ }^{5}$ Clancy (2010: 382-6).

${ }^{6}$ MacQueen \& MacQueen (1989: 295); Skene (1871: 151): 'Sic quidem Deo concedente factum est ut totum sub circio finem Albionis in monarchiam omnium regum primus suscipiens unum feliciter regnum compegerit e duobus'.

${ }^{7}$ 'Iura uero que leges Macalpine dicuntur componens obseruari statuit quarum hactenus quedam restant ac inter populos cursum habent'.

${ }^{8}$ Broun (1999a: 172-3).

${ }^{9}$ Broun (2007: 253-60); Barrow (2003: 192-3).

${ }^{10}$ Broun (1999a: 155-64).
} 
Chronicle of Melrose, datable probably to sometime between 1246 and $1264 .{ }^{11}$ There it is explained that Cinaed is called the first king of Albania (referring presumably to the landmass north of the Forth) 'because he was the first to establish the Scottish laws which they call the laws of mac Ailpín'. ${ }^{2}$

It would appear, therefore, that Scotland's beginnings as a union of Picts and Scots to form a new kingdom was initially formulated in the mid-13th century. As such it coincides with the period when the idea of Scotland as a kingdom equal to any other was actively espoused for the first time (for example, in requests to the pope for coronation and anointment). ${ }^{13}$ This can be taken a step further. The reinterpretation of Cinaed mac Ailpín in the mid-13th century as unifier and law-giver can be seen as a significant element in the narrative that was being fashioned to reflect the emerging idea of Scotland as a sovereign kingdom. It gave Scotland's jurisdictional integrity a point of origin. ${ }^{14}$

What happens, though, if we set aside the narrative of a united kingdom under Cinaed mac Ailpín, and look for Scotland's beginnings before Scotland's independence was fully articulated in the mid-13th century? In this lecture I will seek to explore ways in which a British dimension may be regarded as pivotal for understanding the beginning of Scotland. In the first part I will consider the earliest stage in the emergence of an idea of Scotland in its most basic sense as the country we recognise today. This will centre on the late 12 th century. In the second part I will turn to the origins of the earliest idea of Scotland that can be detected - the notion of Scotland as the country north of the Forth. This will focus on the Picts in particular. It will soon become apparent that in both parts the evidence is too exiguous to allow for demonstrable conclusions, and that my argument is largely based on inference. The overall intention is to use as wide a range of material as possible to develop fresh perspectives that can help us to think more freely about Scotland's beginnings, taking nothing for granted.

\section{THE BEGINNINGS OF THE SCOTTISH KINGDOM AS A SINGLE COUNTRY}

If the idea of Scotland's jurisdictional integrity was a novelty in the mid-13th century, the very idea of the Scottish kingdom as a single country was not much older. This can readily be appreciated by considering what 'Scotland' meant to the king's subjects

\footnotetext{
${ }^{11}$ Anderson \& Anderson (1936: 7); Broun \& Harrison (2007: 149-51).

12 ‘. . . quia primus leges Scoticanas instituit quas vocant leges mac Alpin'.

${ }^{13}$ Broun (2007: 203-6).

${ }^{14}$ Broun (2007: 240-6).
} 
in the 12th century and beginning of the 13 th. ${ }^{15}$ For a start, it appears to have been a commonplace to regard the Firth of Forth and the River Forth as the southern limit not simply of an ancient historic core but of 'Scotland' itself. Historians have become accustomed to refer to the landmass north of the Forth as Scotia (which, of course, is simply the Latin for 'Scotland'). This is certainly convenient, but it should not obscure the fact that, for those living in the 12th century, there was no 'Scotland' in our sense. We capture best the force of this earlier sense of Scotia and the novelty of the notion of the kingdom as a single country if we render Scotia as 'Scotland' throughout this period.

But the situation in the 12th century is even more bewildering. 'Scotland' also referred specifically to a region bounded by Drumalban in the west and the Spey in the north, as well as the Forth in the south. This is made explicit in the text of an assize on the procedure for dealing with accusations of theft which Alice Taylor has recently discussed in her new edition of Leges Scotie. She has argued compellingly that it is an updating of an assize of David I (1124-1153) by his grandson William the Lion (1165-1214). ${ }^{16}$ Another example is in an account of William's last journey from the north down to Stirling, where he died in December 1214. We are told that 'he returned from Moray to Scotland, and then from Scotland he proceeded into Lothian'. ${ }^{17}$ When, then, did 'Scotland' start to be used of the kingdom as a whole?

The first clear-cut examples in a Scottish chronicle of 'Scotland' including all the country south of the Forth to the Tweed and Solway is in material written into the Chronicle of Melrose in 1218 or soon thereafter. ${ }^{18}$ There, events in Berwickshire a couple of years earlier, in 1216, are described as occurring in 'southern Scotland', and a vision in Galloway in the same year is located in 'western Scotland'. A distinction between north and south of the Forth, however, may still be detected in material entered in 1222 when a journey from Edinburgh as far as Aberdeen was referred to as going into profunda Scotia, 'deep Scotland'. ${ }^{19}$

In the 12th century, therefore, 'Scotland' was only one of the regions-we could equally say 'countries' - ruled by the kings of Scots. The other 'countries' each had a different history of becoming part of the Scottish realm. Galloway and Moray, for example, had kings of their own in the early 12 th century. ${ }^{20}$ Moray was conquered by David I following the death in battle of its last king in $1130 .{ }^{21}$ Galloway was subdued

\footnotetext{
${ }^{15}$ Broun (2015).

${ }^{16}$ Taylor (2009: 223-6, 234-5).

17 'de Moravia rediit in Scocia, de Scocia vero profectus in Laudoniam': Skene (1871: 279).

${ }^{18}$ Davies (2016); Broun \& Harrison (2007: 134).

${ }^{19}$ Davies (2016); Broun \& Harrison (2007: 136-7).

${ }^{20}$ Mac Airt \& Mac Niocaill (1983: 1130.4); Stringer (2000: 212).

${ }^{21}$ Oram (1999).
} 
in 1160 and the following year it was split between two brothers. ${ }^{22}$ This led about thirty years later to the creation of the earldom of Carrick and the lordship of Galloway. ${ }^{23}$ The lordship of Galloway was later divided among heiresses following the suppression of a rising in $1235 .{ }^{24}$ Despite falling under the king of Scots' authority, however, Galloway (and also Carrick) still retained distinct arrangements for the administration of justice for the remainder of the 13th century. ${ }^{25}$ Lothian, by contrast, had been ruled by the king of Scots for part of the 10th century and most of the 11th century. ${ }^{26}$ To the west of Lothian, most of the old kingdom of Strathclyde had been controlled by Scottish kings since at least the winter of 1069-70, with the exception of Alexander I's reign (1107-24) when it was ruled by his younger brother, the future David I. ${ }^{27}$ Both Lothian and Strathclyde show that it was perfectly possible to be securely part of the Scottish realm for many generations before 1200, without being part of 'Scotland'. Indeed, there are references in the late 12th century to the region south of the Forth as part of England and to Glasgow as in 'northern Wales' ${ }^{28}$ Both these statements were by leading churchmen who lived in these areas. There is no suggestion, however, that they regarded this as incompatible with loyalty to the Scottish realm. The idea that kingdom and country could be one-and-the-same was only just beginning to emerge.

\section{The Scottish kingdom in the sicut clause in charters}

The earliest clear evidence for this change is to be found in charters. These begin to survive in significant numbers from the $1160 \mathrm{~s} .{ }^{29}$ The increasing use and archiving of charters shows that it had become desirable, although not yet necessary, to have your title to a perpetuity (such as a landed estate) recorded in writing. The form, script and appearance of these documents followed English practice. One aspect of charters in Scotland catches the eye. When land (or other property) was given (e.g. to a monastery) it was often said to be held freely and peacefully. This could be expanded (in the sicut clause) to say that it would be held as freely and peacefully as any other land or similar property was held in the region or the kingdom. Early examples tend to refer to Lothian or 'Scotland' (meaning the country north of the Forth): for instance, in the

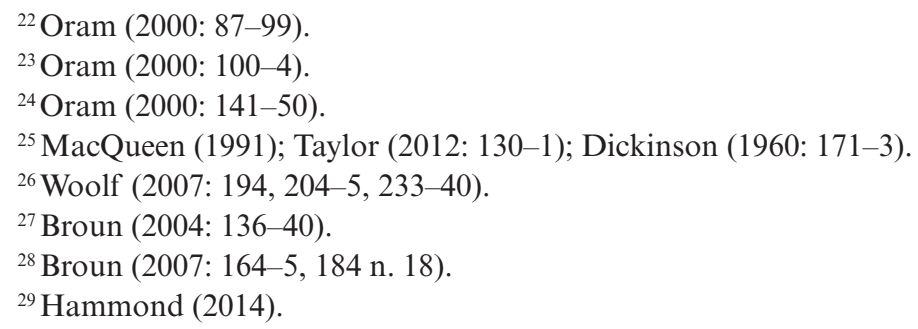


charter of William Maule of Fowlis giving the chapel of Fowlis Easter to St Andrews Cathedral Priory in $1165 \times 1170$, it is explained that the prior and canons of St Andrews will hold the chapel 'as they most freely and quietly hold and possess their alms in "Scotland". ${ }^{30}$ A charter of Philip de Vermelles II for Newbattle Abbey, datable to $1179 \times 1189$, refers simply to the kingdom, explaining that the donation is to be held and possessed 'as any land is best and most freely, most quietly and most honourably held and possessed in the whole kingdom'. ${ }^{31}$ John Hudson has commented that this form of the clause is a distinctive feature of Scottish charters. ${ }^{32}$ There were different ways of referring to the kingdom in this context: the form 'kingdom of Scotland' or 'kingdom of Scots' (regnum Scotie, regnum Scottorum), however, is found in 81 per cent (59 out of 73) of extant non-royal charters datable to before 1200 which include the kingdom in a sicut clause. ${ }^{33}$ The earliest example is in the $1150 \mathrm{~s} .{ }^{34}$ To begin with it was restricted to those at the apex of royal circles. ${ }^{35}$ From the 1180 s, however, the references to the 'kingdom of Scotland/Scots' in this clause becomes more widespread. ${ }^{36}$ It may be inferred from this that law and custom in relation to landholding was now assumed more generally to be the same throughout the realm. ${ }^{37}$ This was new: here, it seems, we have the beginning of a sense of the kingdom as a uniform jurisdictional entity rather than as separate 'countries' with their own laws and customs. This was fundamental for incubating what became the modern sense of 'Scotland'. By defining landholding in relation to the kingdom, those who drafted and authorised these charters (and this included the lord of Galloway) presumably thought of the kingdom as a 'land' itself - a single country. ${ }^{38}$

A British dimension to this new sense of the kingdom as a country is not difficult to find, at least in the background. The substantive land law in question, like the charters themselves, was in its essentials derived from English practice. This is no surprise, given that the lords in whose name these charters were produced were, like the kings of Scots themselves, part of an Anglo-French elite which had extended into Scotland

\footnotetext{
30 'sicut liberius et quiecius ceteras elemosinas suas in Scocia tenent et possident': Thomson (1841: 264 5). For the dating, see http://db.poms.ac.uk/record/source/5651/\# (accessed 21 March 2015).

31 'sicud aliqua [terra] in toto regno melius et liberius quiecius et honorificencius tenetur et possidetur': Innes (1849: no.125). For the dating, see http://db.poms.ac.uk/record/source/5504/\# (accessed 21 March 2015).

${ }^{32}$ Hudson (2003: 131).

${ }^{33}$ Broun (2016a).

${ }^{34}$ Innes (1849: no. 69). The earliest example in an original single sheet is a royal charter datable to 1161 or 1162: Barrow (1960: no. 183).

${ }^{35}$ Broun (2016a).

${ }^{36}$ See below, 113-14.

${ }^{37}$ Stringer (1985: 90).

${ }^{38}$ A striking example is where the king's reference to a church in Tynedale as in 'my land' is rephrased as 'kingdom of Scotland' in a later charter relating to the same gift: Barrow (1971: no. 227); Innes \& Chalmers (1848: no. 37).
} 
during the 12th century, usually from England. ${ }^{39}$ For some the Scottish kingdom became a major or principal area of activity. They nevertheless retained landed and family interests in England, and in some cases France after the loss of Normandy in 1204. ${ }^{40}$ Those who reached the highest ranks of Scottish society often did so through marriage into the leading Gaelic kindreds of eastern and south-western Scotland. By the late 12th century these leading Gaelic kindreds had themselves become part of this Anglo-French elite and acquired lands and connections in England. Matthew Hammond has shown, for example, that by the 1170s, Donnchad II earl of Fife, Morgan earl of Mar and Gilla Brigte (Gilbert) earl of Strathearn were part of a 'vast web' of leading families with the Scottish royal family at the centre, including Aubini Brito, Beaumont (earls of Leicester), Beaumont-sur-Sarthe, Clare, de Quincy, Senlis, Tosny (Conchès and Belvoir) and Warenne. ${ }^{41}$ The geographical reach of this web extended not only into Scotland, England and northern France, but also into Wales and Ireland. They were also pivotal to more local networks, some in the Scottish kingdom, which could link elites in different regions (for example the families and followers of the earl of Fife stretched into Buchan, Carrick and Lothian) ${ }^{42}$ There were other 'vast webs' which connected with elites in the south of the kingdom and northern England, such as that revealed in Keith Stringer's study of the De Vescys. ${ }^{43}$ By the late 12th century, there cannot have been many who exercised lordship in the Scottish realm who were not part of a network that included some who had experience of lordship in England. As David Carpenter has observed, the higher you were in Scottish society, the more likely you were to be aware of developments in England. ${ }^{44}$ This Anglo-French elite would have been acutely conscious that there were two principal kingdoms in Britain. Would this, however, have been sufficient of itself to promote a new sense of the Scottish kingdom as a single country?

It might be said that it was inevitable that, with the passage of time, there would be an increase in the incidence of statements in the sicut clause that land (or other property) was to be held as freely and peacefully as any other similar property in the 'kingdom of Scotland' (or 'of Scots'). The fact that this 'took off' as significantly as it did towards the end of the century is, however, worth considering more closely. ${ }^{45}$ The figures are striking. If we look at charters that are datable definitely to before 1170 ,

\footnotetext{
${ }^{39}$ Barrow (1980).

${ }^{40}$ Stringer (2013).

${ }^{41}$ Hammond (2005: 137-8).

${ }^{42}$ Young (1993); Oram (2000: 89-90).

${ }^{43}$ Stringer (1999). The family's interests stretched across Britain and Ireland in the 13th century. Their profile with regard to the Scottish kingdom is already evident, however, in 1193 when Eustace de Vescy married King William the Lion's illegitimate daughter Margaret (Barrow 1971: 99).

${ }^{44}$ Carpenter (2013: 154).

${ }^{45}$ For a full discussion of the data, see Broun (2016a).
} 
and lay aside those few of David I, Mael Coluim IV and William the Lion, the sicut clause with 'kingdom of Scotland/Scots' is found in the charters of only five individuals: the king's steward, the constable, the bishop of St Andrews, the earl of Fife and the king's mother. ${ }^{46}$ This rises to a further thirty-two individuals plus a married couple in charters definitely before 1200. (Nine of them have charters with date-ranges extending before 1170.) How is this to be explained? Charters were not, of course, the exclusive preserve of those at the apex of royal circles before the 1170s. Neither was there any requirement to refer to the 'kingdom of Scotland' (or 'of Scots') in the sicut clause, or to have a sicut clause at all. Could the answer lie in an intensification of royal justice in Scotland?

\section{Royal and baronial justice in the late 12th century}

Alice Taylor has pointed out that there was no consistent term for a sheriff's jurisdiction until ballia emerged in the $1180 \mathrm{~s} .{ }^{47}$ She has shown that this coincided with royal enactments enhancing or consolidating the sheriff's position in the administration of justice. Two assizes in particular reveal how sheriffs were expected to exercise authority over a specified territory. In 1180 it was stated that the sheriff or a deputy should be present at baronial courts. In 1184 attendance at sheriff courts was insisted onexcept for the very greatest lords (i.e. earls, abbots, bishops), who were required to be present only when a royal justice presided. ${ }^{48}$ In both cases it was assumed that lords would know which sheriffdom their land lay within.

The assize of 1180, on the face of it, was the most intrusive. On closer inspection, however, it can be seen as representing only a limited intensification of royal authority. Royal oversight over the administration of justice was not new: ${ }^{49}$ the novelty in 1180 was in having a mechanism that aspired to implement this generally. But this was not intended as a restriction on lordly jurisdiction. It was explained that a baron could still hold his court if neither sheriff nor king's sergeand was available: ${ }^{50}$ the minimal

\footnotetext{
${ }^{46}$ Countess Ada (Innes (1849: no. 69)); Walter son of Alan, steward of the royal household (Innes (1842: no. 163)); Richard de Moreville, constable of the royal household (Fraser (1847: no. 7)); Bishop Richard of St Andrews (Shead (2015: no. 182)); Donnchad II earl of Fife (Thomson (1841: 242)).

${ }^{47}$ Taylor (2015: chap. 4).

${ }^{48}$ Text and translation is in Taylor (2009: 260-2, 270-1; 282-3, 284). For the dating, see Taylor (2009: 210-12). Taylor (2015: chap. 4) has shown that the kingdom was not divided into two regions under justiciars until shortly after 1220 .

${ }^{49}$ Dickinson (1937: xii-xiii).

${ }^{50}$ Taylor (2009: 283): 'Et si uicecomes cum summonitus fuerit ad curiam baronum non ueniat neque miserit aliquem de seruientibus regis liceat baroni curiam suam legaliter tenere sine forisfacto regis et per legale testimonium' ('And if the sheriff does not come when summoned to baronial courts nor does he send another of the king's sergeands, the baron may hold his court lawfully without the king's forfeiture
} 
requirement, by implication, was to inform the sheriff that the court was taking place. The assize, therefore, can be envisaged as having another function apart from making sure that baronial courts were conducted properly. It also served to reduce the risk of barons losing their courts (i.e. having cases taken away from them) because of a claim that justice had not been done. This was true, of course, if the sheriff or king's sergeand were present, which would have made it difficult for a judgement to be appealed, or for someone within the baron's jurisdiction to take their case elsewhere unless directly to the king in person. But it was equally true if neither the sheriff nor king's sergeand was in attendance (as must often have happened). It was stated that the court would still be valid if they had been told that it was taking place: by implication, it would have the same force as if the sheriff or the king's sergeand were there. The discouragement from challenging baronial justice that can be inferred from the assize of 1180 could help to explain why there is no indication of the routine availability of royal written instructions to sheriffs or justices (or justiciars) for the next fifty years (if that). ${ }^{51}$ When a judicial brieve of the kind familiar in England was introduced in simplified form in 1230, its accessibility appears to have been significantly more restricted than south of the border..$^{52}$

\section{The role of the Anglo-French elite}

Such royal safeguarding of baronial jurisdiction is consistent with Alice Taylor's groundbreaking analysis of the central role of barons in the kingdom's governance as this took shape in the late 12 th and 13 th centuries. ${ }^{53}$ She has argued that the assize of 1180 was directed chiefly with the greater lords in mind (although it would have applied to all those who exercised jurisdiction over life and limb). As we will see, however, it was markedly different from what barons would have experienced in England. David Carpenter has taken this further by considering the contrast between royal government in England and Scotland more generally in the 13th century. He found Scotland to be a haven for lordly power, free from the constraints and threats of the precociously centralised English state. He concluded that this 'gave the Scottish

and by lawful witness'). In the archetype of Assise Regis David (for manuscripts and stemma, see Taylor (2012:: 201-15)), the sentence continued ('assistente semper iudice domini regis'), 'always assisted by the lord king's judex': Taylor (2009: 262 n. 505). Taylor (2012) shows that Assise Regis David was composed in the reign of Robert I (1306-29): there can be little doubt that this reference to the king's judex was added then.

${ }^{51} \mathrm{My}$ understanding of this is derived from Joanna Tucker's unpublished University of Glasgow M.Litt. dissertation on the extant texts of legal brieves (as defined in Barrow (1971: 71-4)) before 1250, and her ongoing work on this. I am extremely grateful to her for sharing this and discussing it with me.

${ }^{52}$ Taylor (2015: chap. 5); Carpenter (2013: 143-51).

${ }^{53}$ Taylor (2015: espec. chaps 3 and 4). 
nobility every reason to embrace a sense of Scottish identity and history, thus marking off Scotland from England'. ${ }^{54}$ Henry II's administrative and legal reforms would have made it obvious to anyone with interests in both Scotland and England that the kingdoms were becoming fundamentally different, particularly in relation to landholding and lordship. This as much as anything else could therefore help to explain why, from the 1170s, it began to make sense especially for those exercising baronial jurisdiction to regard the 'kingdom of Scotland' as a land of common laws and customs and as a point of reference for landholding and lordship. According to this view, the Scottish kingdom could have come to seem united almost by default simply because the landed elite experienced it as a kingdom that was not England - a kingdom where local lordship operated without any significant disturbance.

The use of the sicut clause with reference to the Scottish kingdom, however, was never routine: it was a matter of choice. Could it, therefore, be an occasional reflection of a wider commitment to the Scottish kingdom's separateness from English royal jurisdiction? This would not be the only indication that the Anglo-French elite in Scotland at this time were keen to prevent the king of England's authority reaching north of the border. The crucial background here is William the Lion's capture in 1174 in the great rebellion against Henry II, and the terms for his release known as the Treaty of Falaise. ${ }^{55}$ As a result of the treaty, William went to York in August 1175 to meet Henry II and (in Roger of Howden's words), 'brought with him all the bishops, earls, barons, knights and freeholders of his land, from the greatest even to the least of them, to do homage and allegiance and fealty there to the king of England and his heirs forever, against all men'. ${ }^{56}$ Howden was a royal clerk with recent experience of working for Henry II in his dealings with Scotland and Galloway. ${ }^{57}$ Regardless of how many Scots actually thronged into York Minster, the intention was clear: from Henry II's perspective every freeholder in Scotland had recognised his lordship. In the Treaty it was stipulated that those who performed homage and fealty in person would undertake to obtain the fealty and allegiance to Henry II of anyone who was absent. ${ }^{58}$ It was unprecedented for a king of Scots' authority over his people to be undermined like this. ${ }^{59}$ When Richard I, on acceding to the throne in 1189 , agreed to cancel the Treaty of Falaise for the considerable sum of 10,000 marks, William the Lion could not raise this from his own resources: as William of Newburgh, writing at about this time, put

\footnotetext{
${ }^{54}$ Carpenter (2013: 154).

${ }^{55}$ Carpenter (2003: 224-7).

${ }^{56}$ Stubbs (1867: i. 94-5); Stubbs (1868-71: ii. 79-80); Anderson 1908: 259. On the authorship of these texts, see Stenton (1953) and Corner (1983).

${ }^{57}$ Gillingham (1998).

${ }^{58}$ Stones (1970: 8-9).

${ }^{59}$ Davies (1996).
} 
it, he 'scraped together that sum from his subjects' ${ }^{60}$ The fact that it was paid up promptly suggests that there was, indeed, an eagerness to keep English royal authority out of the Scottish kingdom. The Scottish barons certainly knew how to say 'no': they had refused Henry II's demand two years earlier for a levy to fund a crusade, even though King William had already agreed to it (according to the earliest of Howden's accounts) ${ }^{61}$

The levy would not only have hurt barons in the pocket: it could also have risked undermining the kingdom's status in the eyes of the pope. It was not only the lay elite, moreover, who saw Scottish independence as a safeguard for their own interests. The long struggle by Scottish bishops - particularly Glasgow and St Andrews - to escape the claims of archbishops of York and Canterbury to their obedience was regarded from as early as 1120 as relating directly to the kingdom's freedom. ${ }^{62}$ In this context, however, Henry II's overlordship did not, on the face of it, appear to lead to a heightened sense of regnal unity. In contrast to the lords who began to identify with the kingdom as a single country of shared laws and customs, the late 1170s saw a determined campaign by the bishop of Glasgow to establish the independence of his diocese as a special daughter of Rome. ${ }^{63}$ When the kingdom was finally recognised as a province of the Church (probably in 1189), it was as a collection of bishops directly under the pope rather than with an archbishop of its own. ${ }^{64}$ This extraordinary arrangement, however, was only possible because the bishoprics belonged to a kingdom. It was only for this reason that they could be conceived of (with the exception of Galloway) as a discrete entity distinct from the English kingdom and church. ${ }^{65}$

\section{Henry II and the redefinition of English kingship}

It is not difficult to see how Scottish bishops used the kingdom's status to safeguard a level of jurisdictional freedom that they already enjoyed in the absence of archiepiscopal oversight. Jurisdictional freedom may also have been a key concern for lords contemplating the potential consequences of Henry II's overlordship after 1175. Their willingness to get the Treaty of Falaise rescinded may be explained as a reaction not only to the greater domestic power of a king of England, but specifically to Henry II's 'drive to extend the prerogatives of the crown' (to use Ralph of Diss's words). ${ }^{66}$ Diss

\footnotetext{
${ }^{60}$ Barrow (1960: 54 n. 6) citing Howlett (1884-9: i. 304).

${ }^{61}$ Duncan (1975: 234-5); Stubbs (1867: ii. 44-5).

${ }^{62}$ Broun (2007: 114).

${ }^{63}$ Broun (2007: chap. 5).

${ }^{64}$ Barrell (1995); Broun (2007: 124, 130-5, 141-4).

${ }^{65}$ Broun (2007: chap. 4).

${ }^{66}$ 'regiae titulos dignitatis ampliare procurrans': Stubbs (1876: ii. 371). The identification of Diceto as Diss is shown by his appearance in charters while archdeacon 'of London' as Radulfo de Disci (BL Harley Charter 52. G. 20), Rad' de Disei (BL Lansdowne Charter 679), and Rad' de Disci (BL Harley Charter 52. G. 25).
} 
saw this 'drive' as among the reasons why Henry faced rebellion in $1173-4 .{ }^{67}$ A notable aspect of this was Henry's measures to make royal justice more accessible to freeholders generally, both through new procedures and by recruiting personnel who could represent the king judicially not only in his absence on the Continent but also around the country. ${ }^{68}$ Some of this would, no doubt, have been welcomed by local lords as much as anyone else - but not all of it. For example, when Henry II decreed in the first decade of his reign that anyone complaining of default of justice in their lord's court could bring this to the attention of royal justices, the resources were increasingly available to make this a real option for many people. John Hudson has drawn attention to how this particular measure was described in a poem of the mid-1170s as 'causing the barons . . . much grief, whereby everyone lost his court through a false oath . . . ${ }^{69} \mathrm{In}$ the poem the role of royal justices was as yet limited to when the complainant had worked through the hierarchy of lordship above the court where he claimed he had been denied justice; by the end of Henry II's reign, however, it seems such cases could be heard immediately by royal justices. This slipstreaming of the procedure can be seen as part of a range of even more innovative measures that had been introduced after the war of $1173-4 .^{70}$ One of these, the regular circuits of justices from 1176 , would have made it even easier for freeholders to bring cases that could lead to lords losing their court 'through a false oath'. By the time Ralph of Diss was writing (no later than April 1186, I would argue), Henry II's drive to extend his prerogatives had reached a new degree of intensity. ${ }^{71}$

The Treaty of Falaise was itself one of the earliest moves by Henry II towards a radical redefinition of English kingship in the aftermath of the war. There is no indication that Henry intended on the back of it to extend his legal and administrative reforms into Scotland. Nevertheless, it may be guessed that the Anglo-French elite in Scotland recognised that English kingship had changed, and feared for the future. It will be recalled that all freeholders in the Scottish kingdom were now deemed to have acknowledged Henry II as their lord, both those at the ceremony at York in 1175 and those who were absent from it. ${ }^{72}$ In these circumstances it could have made sense for barons seeking to resist a potential intensification of English royal authority in Scotland to define their landholding north of the border explicitly in relation to an alternative kingdom: this would have offered the best chance of holding the more

\footnotetext{
${ }^{67}$ As pointed out in Hudson (2012: 518).

${ }^{68}$ Hudson (2012: chaps 22 and 23); Brand (1990); Stenton (1965: 75-8); Warren (1973: chap. 9).

${ }^{69}$ Hudson (2012: 512, 518); Van Caenegem (1990-1: ii. no. 420H).

${ }^{70}$ For accounts of Henry II's reforms, see works cited in n. 66 and also Hudson (1996: chaps 5 and 7).

${ }^{71}$ According to my unpublished analysis of the codicology and palaeography of Diss's own master-copy of his historical works (London), Lambeth Palace, MS 8, his account of this period was written into the manuscript 1 December $1185 \times$ not long after 10 March 1186 .
}

${ }^{72}$ See above, 116. 
alarming aspects of Henry II's legal and administrative reforms at bay, not only during Henry II's reign, but afterwards. According to this line of argument, therefore, the spread beyond immediate royal circles of the idea of the Scottish kingdom as a single jurisdiction and a united country could have been triggered directly by Henry II's reforms, and sustained by the continuing contrast between Scotland and England experienced by the Anglo-French elite.

\section{THE BEGINNING OF 'SCOTLAND' (ALBA)}

Here, then, it is possible to recognise a seminal British dimension to the beginning of the idea of Scotland as a single country corresponding to the kingdom's territorythe very beginning of 'Scotland' as we understand the term today. An even more elemental British dimension, however, can be discerned in the origin of the earlier idea of 'Scotland' as the country north of the Forth. This is revealed by the Gaelic name for Scotland: Alba.

Alba did not always refer specifically to northern Britain. There are instances in the Chronicle of Ireland in the 9th century, for example, where the word plainly refers to the island of Britain. ${ }^{73}$ From 900, however, Alba was used regularly in Irish chronicles to refer to the kingdom of Cinaed mac Ailpín's descendants. The Chronicle of Ireland at this point probably acquired its information on Scotland from Dunkeld, so this use of a word for 'Britain' as the kingdom's name could reflect Scottish usage. ${ }^{74}$ It is difficult to say from a linguistic perspective how much of a semantic shift this may have represented. ${ }^{75}$ If we are to assess how radical or otherwise this use of Alba for the kingdom may have been, we must start with references to the kingdom and its people traceable to the Chronicle of Ireland, the principal contemporary source for Pictish affairs in this period. ${ }^{76}$

\footnotetext{
${ }^{73}$ Broun (2007: 80); Dumville (1996).

${ }^{74}$ Broun (2007: 85-6).

${ }^{75}$ For example, this need not have been too radical a shift if the Pictish word for their country was cognate with Alba, like Welsh elfydd (from Celtic *albíiō: see Geriadur Prifysgol Cymru: http://www.geiriadur. ac.uk/, elfydd'(a)) and, akin to elfydd, included 'country' or 'land' within its semantic range. This, rather 'Britain' specifically, could therefore have lain behind the use of Alba in this context. Woolf (2007: 179-80) discusses a potential example of *Albidia as representing a Pictish word for their country (or Brittonic * Albid: see Dumville (2000: 85)), which raises a further possibility that the Pictish name for Pictland may have sounded sufficiently similar to Gaelic Alba for it to have become assimilated to it (although this seems unlikely, given what is known about Pictish phonology: I am very grateful to Guto Rhys for sharing his work and discussing this issue with me). Without more information on what the Pictish word for their country may have been, however, it is difficult to pursue this further.

${ }^{76}$ Charles-Edwards (2006). Until recently the common source of the principal Irish chronicles for this period (the 'Chronicle of Ireland') was regarded as running up to 911. This has been challenged by McCarthy (2008), but the previous consensus has been defended compellingly by Evans (2010).
} 
Superficially the most obvious point is that Pictish terminology was dropped. ${ }^{77}$ Cinaed mac Ailpín himself and his brother, and also his sons (who died in 876 and 878), are described in Latin as 'king of the Picts', rex Pictorum. Their grandsons were each ri Alban, 'king of Alba'. ${ }^{78}$ Picti independently of the royal title is used for the kingdom's inhabitants for the last time in 875. In 918 they are no longer Picti but fir Alban, Gaelic for 'people of Alba'. ${ }^{79}$ The Gaelic term for the 'Pictish people', Cruithentúath, is used in the annal for 866: it appears for the last time in $904 .{ }^{80} \mathrm{How}$ is this disappearance of references to Picts to be explained?

\section{Alba as Gaelic Britain?}

On the face of it the answer seems to lie with the Gaelicisation of Pictland. Indeed, the Anglo-Saxon Chronicle provides compelling evidence that this process had changed the kingdom's identity at much the same time - at least from an English perspective. In the chronicle under the years 920 and 934 'Scotland' and 'Scots', originally the English words for Ireland and Gaelic-speakers, were applied respectively to the former Pictish kingdom and its people. ${ }^{81}$ From then on, where there had once been Peohtas ('Picts'), there were Scottas. It seems natural to explain this as a consequence of the death of the Pictish language and victory of Gaelic. The kingdom, indeed, was explicitly identified as Gaelic, not only by its English neighbours, but in the genealogy of the kings of Alba themselves. The earliest extant texts of the royal genealogy can be dated to the late 10th century; there is no difficulty, however, in supposing that ancestry from Gaelic kings of Dál Riata was asserted earlier. ${ }^{82}$ The possibility that this Dalriadic ancestry was a biological and not just a political reality cannot be ruled out (despite my attempt to do so, which Thomas Charles-Edwards has shown was misguided) ${ }^{83}$

The simplest answer to how Alba, 'Britain', became the kingdom's name, therefore, would be that Alba in this context referred to Gaelic Britain. This is encouraged, on the face of it, by the way the Gaelic world was imagined as Ireland and Alba, particularly in literature. In Aided Néill Noigiallaig, the 'Death-tale of Niall of the Nine Hostages', for example, Níall's epithet is explained as referring to five hostages

\footnotetext{
${ }^{77}$ Broun (2007: 72 and n. 6); Charles-Edwards (2008: 170).

${ }^{78}$ Mac Airt \& Mac Niocaill (1983: 858.2, 862.1, 876.1, 878.2, 900.6, 952.1); (also Hennessey (1866: 862.1, 876.1, 900.5))

${ }^{79}$ Mac Airt \& Mac Niocaill (1983: 875.3, 918.4).

${ }^{80}$ Mac Airt \& Mac Niocaill (1983: 866.1); Hennessey (1866: 904.6).

${ }^{81}$ Broun (2005: 269 and n. 109); Bately (1986: 69, 70); Whitelock et al. (1961: 67, 69).

${ }^{82}$ Broun (1999a: 151, 174); Bannerman (1974: 65-6).

${ }^{83}$ Broun (2005: 264-6); Charles-Edwards (2008: 182 n. 41).
} 
from Ireland and four from Alba (i.e. the whole of Gaeldom), or as five from Ireland and one each from Alba, the English, the Britons and the Franks (where Alba would seem naturally to represent Gaelic Britain). ${ }^{84}$ But there is a problem. Whenever any light is thrown on what Gaelic Alba or English Scotland, or the Latin reflexes of these vernacular terms (Albania and Scotia), meant to any of the kingdom's inhabitants before the 13th century, time and again it is the landmass north of the Forth, or a part of it. ${ }^{85}$ Gaelic was spoken much more widely, spreading in the 10th century from the Firth of Clyde into what became greater Galloway (stretching from Irvine in the north to Annandale in the south), and across the Forth into Lothian; there was also a significant Gaelic-speaking presence south of the Solway Firth. ${ }^{86}$ This geographical limitation does not suggest that the primary meaning of Alba in this context-and therefore the reason why it was deemed to be suitable as the kingdom's name-was because Cinaed's grandsons and descendants claimed to rule all the Gaelic-speakers of Britain. Indeed, there is no text that explicitly promotes such a hegemony. This includes Miniugud Senchusa fher nAlban, 'Explanation of the Genealogy of the People of $A l b a$, whose genealogical scheme was probably, from a 10th-century perspective, confined to the leading kindreds in what had been the Pictish kingdom. (This is clearest in an early-11th-century tract associated with Miniugud Senchusa fher nAlban.$^{87}$ ) It is likely to be misleading, therefore, to translate the title as 'The Explanation of the Genealogy of the (Gaelic) Men of Britain'. ${ }^{88}$ By contrast, Alba is already found before the 10th century referring to a kingdom corresponding to Scotland north of the Forth (as we will see shortly). There can be little doubt, therefore, that this was what Alba meant when it appears from 900 in Irish chronicles as the kingdom of Cinaed mac Ailpín's descendants. The Forth as the country's southern limit remained a core feature of the kingdom's identity into the 13th century, despite its territorial expansion south of the Forth during the 10th century. ${ }^{89}$

This is not to deny that, in a literary context, or from an Irish perspective, Alba could have been understood as 'Gaelic Britain'. Even so, it is notable that the phrase 'Ireland and $A l b a$ ' was more than a geographical shorthand for the Gaelic world: it

\footnotetext{
${ }^{84}$ Ní Mhaonaigh (2004: 184-5, 188).

${ }^{85}$ Broun (2015).

${ }^{86}$ Clancy (2010: 373-5, 386-8); Clancy (2008); Edmonds (2013). As a way of referring to all Gaels in Britain, note the phrase 'do Gaidhelaibh re muir anair', ('among the overseas Gaels of the east'), used in the obit of Mael Coluim IV in Hennessy \& MacCarthy (1887-1901: vol. ii, 1165.8): see Herbert (1999: 97) for translation and discussion.

${ }^{87}$ Broun (2006).

${ }^{88}$ Dumville (2002: 197), with the comment that 'in those ten (or eleven) words I have already given more than one hostage to fortune'.

${ }^{89}$ Broun (2015).
} 
referred to two realms. ${ }^{90}$ The literary imagination that ranged across Ireland and Scotland frequently invoked both a 'king of Ireland' and a 'king of $A l b a$ '. There could even be a 'king of Ireland and $A l b a$ '. These titles were not simply a literary device. In terms of the politics of the period, it would appear to have been generally recognised in the 10th century who the 'king of Ireland' and 'king of Alba' was, while in the 11th century this was contested (much more so in Ireland). ${ }^{91}$ These were not, of course, kingdoms in an administrative or jurisdictional sense: their borders were geographical. The pairing of these realms in the imagination would seem more compelling, therefore, if both were originally thought of as island kingdoms: Ireland and 'Britain'. ${ }^{92}$ Indeed, Crimthann Már mac Fidaig (a legendary ancestor of kings of Munster), who could be referred to as 'king of Ireland and $A l b a$ ', was also imagined going on the high-king's circuit on the island of Britain. ${ }^{93}$ This takes us back to the central puzzle: how is the use of the Gaelic word for 'Britain' to be explained as the name for the kingdom of Cinaed mac Ailpín's descendants?

\section{Alba as 'Pictland'}

The earliest explicit appearance of Alba for the landmass north of the Forth is in a Gaelic stanza describing how Cruithne divided Alba among his seven sons. ${ }^{94}$ Their names correspond to Pictish regions, with Fife in the south and Cait in the north. (The word Cait survives in English Caithness, and in the Gaelic for Sutherland: Cataibh.) The only region that cannot be identified as certainly Pictish is Fidach. Although this is attested as a Gaelic name (as in the father of Crimthann Már), ${ }^{95}$ it may simply mean 'woody' here: it need not be an established area-name at all. The equation of Alba in the stanza with Pictland is confirmed by the name of the sons' father, Cruithne, which is the Gaelic collective noun for 'Picts'. I have argued elsewhere that this stanza was the source for the addition of Cruithne and his seven sons to the beginning of a Pictish king-list probably during the reign of Cinaed mac Ailpín's son, Custantín, between 862 and $876 .{ }^{96} \mathrm{I}$ will return to this king-list later.

This is not the only indication that Alba was the Gaelic for 'Pictland'. If we return to the contemporary chronicle material, and look at it afresh without any prior

\footnotetext{
${ }^{90}$ Herbert (2000).

${ }^{91}$ Woolf (2000); Broun (2016b).

${ }^{92}$ See also Broun (2007: 40-7).

${ }^{93}$ O’Brien (1976: 195 [Rawl.B.502 148a16] and n. s [variant in Book of Leinster]; 132 [Rawl.B.502 138a49: 'dia ndeochaid ... Crimthann mac Fidaig ar cuaird ardríg i nInis Bretan']).

${ }^{94}$ Van Hamel (1929: 5-6); Broun (2007: 77-9).

${ }^{95}$ Note also the genealogy of St Fínán of Kinnitty: Ó Riain (1985: 36 (§211)).

${ }^{96}$ Broun (2007: 78).
} 
assumptions, it would seem natural to suppose that the title rex Pictorum for Cinaed mac Ailpín's sons and rí Alban ('king of $A l b a$ ') for his grandsons must refer to essentially the same kingship. If so, then rí Alban need be no more than a Gaelic rendering of 'king of the Picts'. ${ }^{97}$ The proposition that Alba meant 'Pictland' before the 10th century could also suggest a solution to the puzzle of how 'Scotland' (Alba, Latin Albania or Scotia) could refer merely to the region between Moray in the north, the Forth in the south and the mountains of Drumalban in the west. It is striking that this represents the bulk of Pictland beyond the chief Pictish kingdom of Fortriu, which Alex Woolf has shown was located around the Moray Forth. ${ }^{98}$ It might therefore have originally been 'Pictland' in the sense of being 'the rest of Pictland apart from Fortriu', in the same way as 'Germany' more recently stood originally for the bulk of German speaking lands beyond Austria - i.e. as a catch-all term to refer to a significant area of lordships or communities that collectively lacked a distinctive identity of its own. ${ }^{99}$ In the case of Pictland, a name for this area beyond Fortriu could have arisen once it came to be ruled en bloc by the king of Fortriu, possibly in the aftermath of the Battle of Dunnichen in 685. ${ }^{100}$

Be this as it may, the argument that Alba could denote 'Pictland' before the 10th century still leaves some important loose ends that need to be tackled. Why would the Gaelic word for 'Britain' be used as if it meant 'Pictland'? And why, if the kingdom of Alba was simply Pictland in Gaelic guise, did it become so emphatically Gaelic that an overtly Pictish identity 'disappeared'?

\section{The Picts as Britons}

I have suggested elsewhere that if the Pictish word for 'Pictland' (which is not known) was understood also to mean 'Britain', then this would help to explain the switch from $A l b a$ as 'Britain' to Alba as 'Pictland': Alba in its new context would then have been a translation-borrowing (or calque) on this lost Pictish name for their own country. ${ }^{101}$ There is a suggestive parallel. Welsh writers in Latin before about 1130 frequently referred to Wales as Britannia. They also continued to use Britannia for the island of Britain (or just Roman Britain). ${ }^{102}$ Britannia was not, however, a calque on the Welsh word for Wales. Indeed, there was no word in Welsh in this period exclusively for Wales. Cymry, of course, is the modern Welsh for the 'Welsh' and for 'Wales'

\footnotetext{
${ }^{97}$ Broun (2007: 84-7).

${ }^{98}$ Woolf (2006).

${ }^{99}$ I am grateful to Alex Woolf for this suggestion.

${ }^{100}$ Broun (2016b).

${ }^{101}$ Broun (2007: 71-97).

${ }^{102}$ Broun (2007: 80-1); Pryce (2001).
} 
(depending on how it is spelt). Thomas Charles-Edwards has drawn attention to how Cymry was used ambiguously in the poem, Armes Prydein Vawr ('The Great Prophecy of Britain'), which he dated compellingly to sometime in or between 927 and 942: he argued that Cymry denoted not simply the Welsh, but also 'included' 'other Britons as one people, Cymry'. ${ }^{103}$ A similar pattern is evident in other parts of the Brittonic world, with Latin Britannia and vernacular Cymry used for a large-scale kingdom or territory as well as implicitly for the island of Britain and the Britons as a whole. ${ }^{104}$ The kingdom that expanded south from Strathclyde in the 10th century is an example, leaving a legacy of terminology that included Britannia as well as Cumbria and Cambria (from Cymry). ${ }^{105}$ British identity in these instances reflected a sense of being the true indigenous inhabitants of the island, to whom it rightly belonged, in opposition to incomers, particularly the English. The key question for understanding how Gaelic Alba came to be used for 'Pictland', therefore, is not whether this reflects the lost Pictish word for their country: it is whether the Picts, too, regarded themselves as the 'true Britons' (as it were), and (if so), in opposition to whom. What was so British about Pictland that made it seem readily acceptable to use Alba to refer to it, and to do so routinely after 900 ?

It would be attractive to see this as simply another instance of part of the Brittonic world using the word for 'Britain' in another language to denote their particular country or kingdom. On the face of it this is perfectly plausible. It is now generally agreed that the Picts spoke a 'P-Celtic' language: indeed, toponymists have found it difficult to identify elements in Scotland's Brittonic place-names that were distinctively Pictish rather than British. ${ }^{106}$ But there is an indication that the Picts were seen as in some sense distinct from the Britons. In Old Welsh there were two related words, Prydein (or Prydain) and Prydyn. Prydyn may originally have referred to Britain north of the Forth. Like Cruithne, the Gaelic word for Picts which we have met earlier, it derives ultimately from the same word: *Priteni. If so, then Prydein/Prydain may have originally denoted Britain as a whole, or Britain south of the Forth: it is cognate with Latin Britannia. ${ }^{107}$ The exact semantic significance of these terms is muddied by the fact that Prydein and Prydyn were used interchangeably in some of our earliest texts (including Armes Prydein Vawr). ${ }^{108}$ This instability is striking. The crucial point, is that both words, Prydein/Prydain and Prydyn, survived: one did not subsume the

\footnotetext{
${ }^{103}$ Charles-Edwards (2013: 529; 520-1, 527-32) for the dating of Armes Prydein Vawr.

${ }^{104}$ Charles-Edwards (2013: 529-30).

${ }^{105}$ Edmonds (2014); Broun (2007: 124-6).

${ }^{106}$ Forsyth (1997a); Taylor (2011). The only element 'with any claim to be exclusively Pictish in terms of historical Pictland' is *cuper, 'confluence': Taylor (2011: 76).

${ }^{107}$ Jackson (1954); Broun (2007: 81-3).

${ }^{108}$ Examples of Prydein appearing where Prydyn would be expected are listed in Haycock (2013: 93).
} 
other. It was possible to use both words to refer to 'Pictland' in particular, depending on context. ${ }^{109}$ This could not be done for any other Brittonic country. ${ }^{110}$

The reason why it may have made sense to single out 'Pictland' in this way could be that the River Forth and the boggy terrain immediately north of the river was perceived as dividing the island of Britain in two. This was exaggerated wildly in the medieval imagination: Matthew Paris (d.1259), in his celebrated map of Britain, portrays the landmass north of the Forth as an island linked to the rest of Britain by Stirling Bridge alone. ${ }^{111}$ This division of Britain at the Forth was a constant feature in later medieval maps (although not as vividly depicted as by Matthew Paris). ${ }^{12}$ This was not a medieval cartographical quirk: it is noteworthy how the idea of this division of Britain could arise independently. At one chronological extreme we have Tacitus, Agricola, chapter 23, where he refers to the enemies of Rome being pushed back north of the firths of Forth and Clyde 'as if into another island'. ${ }^{113}$ At the other extreme, Walter Bower in his Scotichronicon, writing in the 1440s, recounted a story in which someone at Glastonbury Abbey described Bannockburn as fought 'beside the royal burgh of Stirling in Scotland, lying on the boundary of Britain'. ${ }^{114}$ Bower added that 'it is said that the bridge over the Forth at Stirling lies between Britain and Scotland, forming the border of both'. ${ }^{115}$ This idea that Britain was almost cut in two at Stirling vividly conveys the difficulty of crossing this area before modern times. Apart from the Drip Ford (and later Stirling Bridge nearby), the only route readily available by land to travellers on the move between north and south was through the River Forth at the Fords of Frew. ${ }^{116}$ We can assume that anyone local would have known how to negotiate their way through this difficult terrain. For anyone else, however, it must have seemed a formidable obstacle: the easiest passage was by boat across the Firth of Forth. ${ }^{117}$ It was, presumably, through the memory of experiencing this, and sharing it

${ }^{109}$ Broun (2007: 82, 95 n. 73). The opposite is also true: Haycock (2013: 93) notes that 'in poetry, it [Prydyn] might be taken as a synonym of Prydein rather than a designation for Pictland or its inhabitants'.

${ }^{110}$ The only other context would be if Prydain/Prydein and Prydyn could be understood to refer to Roman Britain as a whole rather than the island. It is difficult, however, to identify clearcut examples.

${ }^{111}$ Harvey (1992: 114-16); Broun (2007: 54).

${ }^{112}$ Parsons (1958: 11); Crone (1961: plates 2-8).

113 'velut in aliam insulam': Hutton \& Peterson (1970: 70).

${ }^{114}$ Shead, Stevenson \& Watt (1991: 356): 'qui locus est juxta burgum regium de Strivelyne in Scocia ad fines Britannie constitutus'.

${ }^{115}$ Shead, Stevenson \& Watt (1991: 356): 'Dicitur enim quod pons Striveline de Forth situatur inter Britanniam et Sciciam utriusque marginem apprehendens'.

${ }^{116}$ Broun (2007: 54).

${ }^{117}$ The two main crossings, Queensferry and Earlsferry, were presumably already much travelled before free passage for pilgrims was established by Queen Margaret (d.1093) and Earl Donnchad I. For Earlsferry, see Taylor \& Márkus (2009: 272). 
with others, that the fissure at the Forth became such a vivid image for people far away from the Forth itself. The impression that this nearly formed an island would appear, indeed, to have gained such a hold on the way this part of Britain was imagined that even someone like Walter Bower, whose abbey of Inchcolm sat in the Firth of Forth, could entertain the idea that it constituted the northern limit of Britain.

\section{The Picts as the people of north of the Forth}

The Picts are, of course, the people of Britain north of the Forth par excellence. The principal means of identifying them is the corpus of over two hundred sculptured stone monuments with distinctive symbols that are distributed from the Western and Northern Isles to Fife in the south: indeed, there is an example a couple of miles inland from the southern shore of the Firth of Forth, the only one south of the Forth. ${ }^{118}$ The symbols also adorn caves and metalwork. They also appear in two places carved onto living rock, but not in Pictland itself, so this activity presumably represents a different context from the use of these symbols on monuments. ${ }^{119}$ It is the use of these symbols specifically on stone monuments that enable us to identify the Picts.

The majority of the monuments are undressed stones with incised symbols (the so-called 'Class I' stones). Some symbols are also found on dressed slabs with an ornate cross on one face and often a secular scene on the other (the so-called 'Class II' stones). The coincidence between the Forth and the southern limit of Pictish symbol stones (bar the single outlier) hardly seems to warrant any comment: what would be more natural than that these stones are located where the Picts lived? It would be unwise, however, to presume that the Picts could not help using these symbols on monuments any more than they could help speaking their native tongue. Sculpture is a deliberate act, requiring specialist skill and patronage. ${ }^{120}$ The discipline involved in their production can be seen in the notable consistency in the style of Class I stones. ${ }^{121}$ There is also a common layout: either symbols are deployed in pairs (sometimes with a mirror or mirror and comb), or a single animal (or, indeed, human) is depicted. A range of about forty distinctive symbols is repeated across the corpus. ${ }^{122}$ The meaning of the symbols may be impossible to retrieve, but the mere fact of their existence on these monuments could be seen as pointing to a conscious decision by Picts to distinguish themselves from others. These 'others' must have included the Britons south of the Forth. Indeed, Katherine Forsyth has recently argued that the symbol

\footnotetext{
${ }^{118}$ Fraser (2008: no.77); Forsyth (2009: 34).

${ }^{119}$ Fraser (2008: nos. $\left.74 \& 75\right)$.

${ }^{120}$ Gondek (2003: 48-59).

${ }^{121}$ I am grateful to John Higgitt for first alerting me to this.

${ }^{122}$ Forsyth \& Driscoll (2009: 38).
} 
stones were specifically inspired by a desire to be different from the Britons. ${ }^{123}$ Let us consider this further.

The 'Class I' stones have been described as archaeologically the exact equivalent of the inscribed memorial stones that are found throughout Celtic Britain. ${ }^{124}$ Katherine Forsyth has taken this further by suggesting that they are best understood as part of a wider movement of inscribed monuments that flourished between the 5th and early 7 th centuries. ${ }^{125}$ This is consistent with some recent archaeological evidence from Rhynie in Aberdeenshire that suggests that the sculptured stones there may date from the 6th century. ${ }^{126}$ Elsewhere in Britain the inscriptions are predominantly, although not exclusively, in Latin letters. Seen in this light, the Picts' use of distinctive symbols looks like a conscious decision to avoid an explicit association with Romanitas. This has led Katherine Forsyth to suggest that 'it is tempting to see the contrasting monumental traditions of southern Scotland and Pictland - Latin-inscriptions versus symbol stones - as an epigraphic manifestation of a mutual desire to distinguish themselves from one another'. ${ }^{127}$ Pictish distinctiveness continued after the 7th century: Forsyth has calculated that about 15 per cent of monuments in England had runes, less than 1 per cent in Ireland used Ogham, whereas Latin letters were the rule in Wales. Pictland, by contrast, stands out for its 'marked preference there for non-roman script'. ${ }^{128}$ This is not because Pictish sculptors in the 8th and 9th centuries were cut-off from outside influences, as Isabel Henderson has shown. ${ }^{129}$ It would seem that the development and maintenance of these symbols was a matter of choice. On the basis of Katherine Forsyth's recent work, it is possible to see this as representing a sustained rejection of Latin forms of self-identification in a secular context, marking a deliberate move to be distinct from Britons in the south. This would be even clearer if, as Katherine Forsyth has suggested, the symbols were used on these monuments to name individual Picts, in much the same way as Latin letter inscriptions south of the Forth named individual Britons. ${ }^{130}$

James Fraser has also suggested that 'there is good reason to believe that many Picts in the early 8th century had convinced themselves that a mutual lack of interest in "the Romans", however they defined them, was central to their ethnic identity'. ${ }^{131}$ He points, for example, to Bede's report of King Naiton's letter to Abbot Ceolfrith in

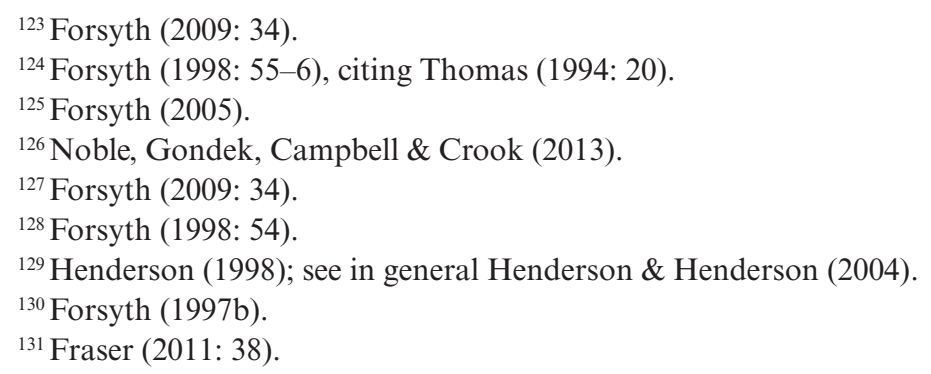


the early 8th century, in which Naiton is said to have referred to his people as being 'separated for a long time from the Roman language and nation'. ${ }^{132}$ Fraser emphasised that Pictish churchmen nonetheless participated fully in Latin culture. Romanitas was only problematic in a particular situation - a situation that was presumably linked intimately with monumental sculpture. If we ask what context would most readily have involved the commemoration of significant individuals in a way that was intended to endure in the landscape, the answer that readily comes to mind is kinship and landholding. ${ }^{133}$

We can only speculate, however, about how the Picts' specifically saw themselves in relation to Britons in the south. Perhaps they made some kind of claim to be the continuation of the indigenous inhabitants of the island who lay outside the Roman Empire. This would only have been enhanced, presumably, by the presence of Antonine's Wall, which to this day etches the landscape between the Forth and the Clyde. ${ }^{134}$ Be this as it may, there is a clear statement in the 9th century of one of the ways that Picts could imagine Pictland. It was as an ancient kingdom encompassing the entire mainland north of the Forth. It is striking that this corresponds so well with the location of Class I Pictish stones (especially if the islands were understood to go with the mainland - for example, Shetland is referred to in medieval Gaelic as Innse Catt, 'the islands of Cait': it will be recalled that Cait was the northern region of the mainland). ${ }^{135}$ This suggests a continuity of some conception of Pictishness focused on the landmass north of the Forth, even if it did not necessarily always take the form of an imagined ancient kingdom.

\section{North of the Forth as an ancient kingdom}

The statement that Pictland formed an ancient kingdom is found in the longer version of the king-list (which we have met briefly already). ${ }^{136}$ It was longer because of the addition of forty-four kings to the beginning of the list. This not only endowed the kingship with an extended succession deep into the past; it also began with a portrayal of the kingdom they ruled as stretching from Fife to Caithness. This was achieved by forming Cruithne's seven sons - who, it will be recalled, each represented a Pictish region - into a single succession, beginning with Cruithne himself. The latest king in the original version of this king-list was probably Custantín son of Cinaed mac Ailpín,

\footnotetext{
${ }^{132}$ Fraser (2011: 35), citing Bede, Historia Ecclesiastica, bk. V, chap. 21 (Colgrave \& Mynors (1969: 532)): 'longe a Romanorum loquella et natione segregati'.

${ }^{133}$ Driscoll (1988).

${ }^{134}$ Breeze (2008).

${ }^{135}$ Watson (1926: 30).

${ }^{136}$ See above, 122.
} 
who died as 'king of the Picts' in $876 .{ }^{137}$ This image of the landmass north of the Forth as an ancient kingdom was evidently created with him in mind as its current ruler.

It will be recalled that, in the earlier stanza-version of the legend of Cruithne's seven sons, the Gaelic word for 'Britain', Alba, was used for 'Pictland': from the 10th century, as we have seen, this usage of Alba became routine. And yet, if we see the longer king-list as a continuation of the deliberate distinction between north and south of the Forth represented by the sculptured symbol stones, it would seem that the Picts had a keen sense of their country as separate from Britannia, or as an alternative Prydein. This idea of being a distinct and different 'Britain' could be explained if the Picts regarded themselves as more British than the Britons. They would not, like other Britons, have thought of their country as part of Britain, but as Britain par excellence.

Finally, how are we to explain the demise of Pictish identity? The eventual abandonment of Pictish symbols could point to the kind of fundamental social change that might also have triggered the widespread switch from speaking Pictish to Gaelic. ${ }^{138}$ Even if this was the case, however, it would be unwise to assume that Gaelic itself was intrinsically inimical to Pictish identity. ${ }^{139}$ For example, the names of the forty-four kings added to the king-list, including Cruithne and his seven sons, were rendered in Gaelic form, rather than in the Pictish forms found in the rest of the text. ${ }^{140}$ Plainly the author saw nothing incongruous about using Gaelic to enhance a core aspect of Pictish identity. This would be all the more striking, of course, if Custantín son of Cinaed mac Ailpín - the king for whom, it seems, the longer king-list was writtenwas himself descended in the male line from kings of Gaelic Dál Riata: it will be recalled that his dynasty's Gaelic identity was asserted in the earliest traceable text of the royal genealogy in the late 10 th century. ${ }^{141}$ Be this as it may, when the Picts became Gaelic speakers their identification with the landmass north of the Forth would not have been disturbed: as noted earlier, this remained a key feature of the idea of

\footnotetext{
${ }^{137}$ Broun (2007: 76).

${ }^{138}$ Broun (1994); Woolf (2007: 326-40); see also Clancy (2010: 382-6).

${ }^{139}$ The explanation for the 'destruction' of the Picts given in the Chronicle of the Kings of Alba (see Woolf (2007: 88-96), and Dumville (2000), for this text) has been taken by Hudson (1998: 133) to show such animosity to the Picts (by a Gael writing in Latin) that he suggests it was written by a contemporary witness. Wormald (1996) and Clancy (2010: 385-6) also regard this as evidence for contemporary ideological hostility to the Picts. If it was written in the second half of the 9th century, it would presumably have been derived from the putatively Dunkeld annalistic source (Broun (1999b)), given that the Chronicle of the Kings of Alba was first formed (at the earliest) in the reign of Illulb (954-62). But (as Woolf (2007: 93-5) explains) the terms of reference and expression are more readily explained as a later (probably 12th-century) elaboration made when it was already assumed that the Picts had disappeared.

${ }^{140}$ Broun (2007: 75-6).

${ }^{141}$ See above, 120.
} 
'Scotland' up to the 13th century. ${ }^{142}$ Indeed, the sense of being different from the rest of Britain would, if anything, have been enhanced. As Gaels the people of Alba would have been even more distinct from Britons than they had been as Picts. (There was still an ostensibly British kingdom based on the Clyde until the 11th century. ${ }^{143}$ ) Being Gaels would also have made them clearly different from the other main population-groups on the island. This could explain why, once the Picts had turned to Gaelic, the kingdom's Gaelic identity was highlighted.

\section{SCOTLAND AND BRITAIN}

The initial premise of this lecture was that the idea of Scotland beginning as a union of Picts and 'Scots' can be traced back to the 13th century, and can therefore best be understood not as an actual event but as a reflection of a new vision of the kingdom as a jurisdiction on a par with any other kingdom. This vision was part of a broader European development of a new way of conceptualising kingdoms and peoples that can be recognised as the seed of the notion of national sovereignty. ${ }^{144}$ Presumably the idea of a Pictish-Scottish union was coined and became established in the 13th century because it provided a satisfyingly self-contained account of Scotland's beginnings that chimed with assumptions about the jurisdictional integrity and independence of the Scottish kingdom at that time. Certainly the creation of a kingdom of Picts and Scots by Cinaed mac Ailpín has had a remarkably long life as a 'given' of Scottish history. It is embedded in the standard numeration of kings: Cinaed, as 'Kenneth I', and his son, 'Constantine I', were not the first kings of Picts to bear these names, and yet, as far as our contemporary evidence is concerned, they each died as rex Pictorum. ${ }^{145}$ Presumably one of the enduring attractions of Cinaed's union has been that it allowed little or no space for a fundamental British dimension to Scottish origins: both Picts and 'Scots' were obviously distinct from Britons or English.

In this lecture I have argued that the removal of the union of Picts and Scots from the picture offers an opportunity to rethink Scotland's origins and how this relates to Britain. A keen awareness of Scotland's position as part of Britain can be seen as of pivotal significance in explaining the country's beginnings both in the most basic sense of 'Scotland' that we understand today and in its earlier sense as the country north of the Forth. The conception of the Scottish kingdom as a land of common laws and customs may first be perceived in the 1150 s, but I have argued that they only caught

\footnotetext{
${ }^{142}$ See above, 110.

${ }^{143}$ Broun (2004: 125-40); Edmonds (2014).

${ }^{144}$ Ullmann (1949); Tierney (1954); see also Reynolds (1997: chap. 8).

${ }^{145}$ See above, 120.
} 
on beyond those at the pinnacle of royal circles as, at least in part, an unintended consequence of Henry II's legal and administrative reforms in England. This hinges crucially on the fact that Anglo-French lords in Scotland had landed and family interests in England that would have given them personal knowledge of the impact of Henry II's drive to enhance his prerogatives. As far as the earlier appearance of $A l b a-$ the modern Gaelic for 'Scotland'-in anything like its current guise is concerned, this, too, can be explained as a continuation of a core aspect of Pictish identity, rooted in a sense of being distinctively British.

Although I have argued that a British dimension is pivotal for understanding the very beginnings of Scotland in its earliest and its modern senses, it is noticeable that in both cases the overriding concern was to accentuate Scotland's separateness from the south. This would help to explain the baronial interest in invoking the Scottish kingdom when defining landholding and lordship, and also account for the deliberate distinctiveness of the Picts. Unlike some English or Welsh identifications with Britain, which took the whole island as their starting-point, ${ }^{146}$ the British element of medieval Scottish identity had differentiation and division from the rest of Britain at its heart. Being British may be an essential element of any explanation of Scotland's beginnings, but it would be a mistake to extrapolate from this an image of Britain's ultimate unity. On the contrary, there would seem to be an irreconcilable tension between the Scottish version of Britishness as presented here and those versions of Britishness in which the island's integrity is treated as a given. If we are to extrapolate anything of general significance from this, it is that the problematic nature of Scotland's relations with Britain's predominant country, England, has the deepest of roots. Perhaps we should not be surprised if Scotland's place within a British state is, for at least a significant element of Scots, a matter of recurring concern, and that ultimately it is incapable of being permanently settled.

Acknowledgements: I am very grateful to Thomas Clancy, Katherine Forsyth and Alice Taylor for their comments on particular passages, and to Thomas Clancy and Katherine Forsyth for offprints. I am especially grateful to Joanna Tucker for reading all but the early medieval part and for her perceptive comments and queries, which has led to crucial improvements. I would also like to acknowledge the assistance of the Arts and Humanities Research Council for funding the project (AH/H040110/1: 'The Breaking of Britain: cross-border society and Scottish independence 1216-1314) whose research informs the section on the beginning of the Scottish kingdom as a single country. Any flaws that remain are my own responsibility entirely. I am also for ever grateful to Nerys Ann Jones for her continuing support.

${ }^{146}$ Broun (2007: 21-3, 40-53). 


\section{REFERENCES}

Anderson, A. (1908), Scottish Annals from English Chroniclers A.D. 500 to 1286 (London, David Nutt).

Anderson, A. \& Anderson, M. (eds) (1936), The Chronicle of Melrose from the Cottonian Manuscript, Faustina B. IX in the British Museum, with an index by W. Croft Dickinson (Studies in Economics and Political Science; London, London School of Economics and Political Science).

Bannerman, J. (1974), Studies in the History of Dalriada (Edinburgh, Scottish Academic Press).

Barrell, A. (1995), 'The Background to Cum Universi: Scoto-Papal Relations 1159-1192', Innes Review, 46: 116-38. http://dx.doi.org/10.3366/inr.1995.46.2.116

Barrell, A. (2000), Medieval Scotland (Cambridge Medieval Textbooks; Cambridge, Cambridge University Press).

Barrow, G.W.S. (ed.) (1960), Regesta Regum Scottorum, vol. i, The Acts of Malcolm IV, King of Scots 1153-65 (Edinburgh, Edinburgh University Press).

Barrow, G.W.S. (ed.) (1971), Regesta Regum Scottorum, vol. ii, The Acts of William I, King of Scots 1165-1214, in collaboration with W.W. Scott (Edinburgh, Edinburgh University Press).

Barrow, G.W.S. (1980), The Anglo-Norman Era in Scottish History (Oxford, Oxford University Press).

Barrow, G.W.S. (2003), The Kingdom of the Scots: Government, Church and Society from the Eleventh to the Fourteenth Century, 2nd edn (Edinburgh, Edinburgh University Press).

Bately, J. (ed.) (1986), The Anglo-Saxon Chronicle. A Collaborative Edition, gen. eds D. Dumville \& S. Keynes, vol. ii, $M S A$ (Cambridge, The Boydell Press).

Brand, P. (1990), “Multis vigiliis excogitatam et inventam": Henry II and the Creation of the English Common Law', Haskins Society Journal, 2: 197-222.

Breeze, D. (2008), Edge of Empire. Rome's Scottish Frontier: the Antonine Wall, principal photography by David Hendrie (Edinburgh, Birlinn).

Broun, D. (1994), 'The Origin of Scottish Identity in its European Context', in B.E. Crawford (ed.), Scotland in Dark Age Europe (St Andrews, St John's House), 21-31.

Broun, D. (1999a), The Irish Identity of the Kingdom of the Scots in the Twelfth and Thirteenth Centuries (Studies in Celtic History; Woodbridge, Boydell and Brewer).

Broun, D. (1999b), 'Dunkeld and the Origin of Scottish Identity', in D. Broun \& T.O. Clancy (eds), Spes Scotorum: Hope of Scots (Edinburgh, T \& T Clark), 95-111.

Broun, D. (2004), 'The Welsh Identity of the Kingdom of Strathclyde, ca 900-ca 1200', Innes Review, 55: 111-80. http://dx.doi.org/10.3366/inr.2004.55.2.111

Broun, D. (2005), 'Alba: Pictish Homeland or Irish Offshoot?', in O’Neill, P. (ed.), Exile and Homecoming. Papers from the Fifth Australian Conference of Celtic Studies, University of Sydney, July 2004 (Sydney Series in Celtic Studies; Sydney, University of Sydney), 234-75.

Broun, D. (2006), 'The Genealogical 'Tractates' Associated with Miniugud Senchusa fher nAlban', Northern Scotland, 26. This volume has yet to be published.

Broun, D. (2007), Scottish Independence and the Idea of Britain from the Picts to Alexander III (Edinburgh, Edinburgh University Press).

Broun, D. (2015), forthcoming, 'Rethinking Scottish Origins', in S. Boardman \& S. Foran (eds), Barbour's Bruce and its Contexts: Politics, Chivalry and Literature in Late Medieval Scotland (Woodbridge, Boydell \& Brewer).

Broun, D. (2016a), forthcoming, 'Identifying with the Scottish Kingdom: the Evidence of TwelfthCentury Charters', in K.J. Stringer \& A. Winchester (eds), Northern England and Southern Scotland from the Tenth to the Thirteenth Centuries (Woodbridge, Boydell \& Brewer).

Broun, D. (2016b), forthcoming, 'The Origins of the Mormaer', in D. Crouch and H. Docherty (eds), The Earl in Medieval Britain (Woodbridge, Boydell \& Brewer).

Broun, D. \& Harrison, J. (2007), The Chronicle of Melrose Abbey. A Stratigraphic Edition. 3 vols. vol. i, Introduction and Facsimile Edition (Woodbridge, Scottish History Society/The Boydell Press). 
Carpenter, D. (2003), The Struggle for Mastery: Britain 1066-1284 (The Penguin History of Britain; London, Allen Lane/Penguin).

Carpenter, D. (2013), 'Scottish Royal Government from an English Perspective', in M. Hammond (ed.), New Perspectives on Medieval Scotland, 1093-1286 (Woodbridge, Boydell \& Brewer), 117-55.

Charles-Edwards, T.M. (trans.) (2006), The Chronicle of Ireland, with introduction \& notes (Translated Texts for Historians; Liverpool, Liverpool University Press).

Charles-Edwards, T.M. (2008), 'Picts and Scots', Innes Review, 59: 168-88.

http://dx.doi.org/10.3366/E0020157X08000279

Charles-Edwards, T.M. (2013), Wales and the Britons, 350-1064 (Oxford, Oxford University Press).

Clancy, T.O. (2008), 'The Gall-Gàidheil and Galloway', Journal of Scottish Name Studies, 2: 19-50.

Clancy, T.O. (2010), 'Gaelic in Medieval Scotland: Advent and Expansion', Proceedings of the British Academy, 167: 349-92.

Corner, D. (1983), 'The Gesta Henrici Secundi and Chronica of Roger, Parson of Howden', Bulletin of the Institute of Historical Research, 56: 297-310.

http://dx.doi.org/10.1111/j.1468-2281.1983.tb01767.x

Crone, G.R. (1961), Early Maps of the British Isles A.D. 1000-A.D. 1579 (London, Royal Geographical Society).

Davies, J.R. (ed.) (2016), forthcoming, The Chronicle of Melrose Abbey. A Stratigraphic Edition, vol. iii (Woodbridge, Scottish History Society/The Boydell Press).

Davies, Rees (1996), “Keeping the Natives in Order": the English King and the "Celtic" Rulers 1066-1216', Peritia, 10: 212-24.

Dickinson, W.C. (ed.) (1937), The Court Book of the Barony of Carnwath, 1523-1542 (Edinburgh, Scottish History Society).

Dickinson, W.C. (1960), 'Surdit de Sergaunt', Scottish Historical Review, 39: 170-5.

Driscoll, S.T. (1988), 'Power and Authority in Early Historic Scotland: Pictish Symbols and Other Documents', in J. Gledhill, B. Bender \& M.T. Larsen (eds), State and Society: the Emergence and Development of Social Hierarchy and Political Centralization (London, Unwin Hyman), 215-35.

Dumville, D. (1996), 'Britain and Ireland in Táin Bó Fraích', Études Celtiques, 32: 175-87.

Dumville, D. (1997), The Churches of North Britain in the First Viking-Age. The Fifth Whithorn Lecture, 14th September 1996 (Whithorn, Friends of the Whithorn Trust).

Dumville, D. (2000), 'The Chronicle of the Kings of Alba', in S. Taylor (ed.), Kings, Clerics and Chronicles 500-1297. Essays in honour of Marjorie Ogilvie Anderson on the occasion of her ninetieth birthday (Dublin, Four Courts Press), 73-86.

Dumville, D. (2002), 'Ireland and North Britain in the Earlier Middle Ages: Contexts for Míniugud Senchusa Fher nAlban', in C. Ó Baoill \& N. McGuire (eds), Rannsachadh na Gàidhlig 2000. Papers Read at the Conference Scottish Gaelic Studies held at the University of Aberdeen 2-4 August 2000 (Aberdeen, An Clò Gaidhealach), 185-212.

Duncan, A.A.M. (1975), Scotland: the Making of the Kingdom (The Edinburgh History of Scotland; Edinburgh, Oliver \& Boyd).

Duncan, A.A.M. (2002), The Kingship of the Scots, 842-1292: Succession and Independence (Edinburgh, Edinburgh University Press).

Edmonds, F. (2013), 'The Furness Peninsula and the Irish Sea Region: Cultural Interaction from the Seventh Century to the Twelfth', in C. Downham (ed.), Jocelin of Furness: Essays from the 2011 Conference (Donington, Shaun Tyas), 17-44.

Edmonds, F. (2014), 'The Emergence and Transformation of Medieval Cumbria', Scottish Historical Review, 93: 195-216. http://dx.doi.org/10.3366/shr.2014.0216

Evans, N. (2010), The Present and the Past in Medieval Irish Chronicles (Studies in Celtic History; Woodbridge, Boydell \& Brewer). 
Forsyth, K. (1997a), Language in Pictland: the Case Against 'non-Indo-European Pictish'. A. G. Van Hamel Lecture 1995 (Utrecht, De Keltiche Draak).

Forsyth, K. (1997b), 'Some Thoughts on Pictish Symbols as a Formal Writing System', in D. Hendry (ed.), The Worm, the Germ and the Thorn. Pictish and Related Studies Presented to Isabel Henderson (Balgavies, Pinkfoot Press), 85-98.

Forsyth, K. (1998), 'Literacy in Pictland', in H. Pryce (ed.), Literacy in Medieval Celtic Societies (Cambridge Studies in Medieval Literature; Cambridge, Cambridge University Press), 183-201.

Forsyth, K. (2005), 'HIC MEMORIA PERPETUA: the Inscribed Stones of Sub-Roman Southern Scotland', in S. Foster \& M. Cross (eds), 'Able Minds and Practiced Hands': Scotland's Early Medieval Scupture in the 21st Century (Society for Medieval Archaeology; Oxford, Historic Scotland), 113-34.

Forsyth, K. (2009), 'The Latinus Stone: Whithorn's Earliest Christian Monument', in J. Murray (ed.), St Ninian and the Earliest Christianity in Scotland. Papers from the Conference held by The Friends of the Whithorn Trust in Whithorn on September 15th 2007 (Oxford, Archaeopress), 19-41.

Forsyth, K. \& Driscoll, S.T. (2009), 'Symbols of Power in Ireland and Scotland, 8th-10th Century', Territorio, Sociedad y Poder. Revista de Estudios Medievales, 2: 33-65.

Fraser, I. (ed.) (2008), The Pictish Symbol Stones of Scotland (Edinburgh, Royal Commission on the Ancient and Historical Monuments of Scotland).

Fraser, J. (2011), 'From Ancient Scythia to the First Dundee Summer School: Thoughts on The Problem of the Picts and the Quest for Pictish Origins', in S.T. Driscoll, J. Geddes \& M.A. Hall (eds), Pictish Progress. New Studies on Northern Britain in the Early Middle Ages (Leiden, Brill), 15-43.

Fraser, W. (ed.) (1847), Liber Sancte Marie de Dryburgh (Edinburgh, Bannatyne Club).

Gillingham, J. (1998), 'The Travels of Roger of Howden and his views of the Irish, Scots and Welsh', in C. Harper-Bill (ed.), Anglo-Norman Studies XX, Proceedings of the Battle Conference 1997 (Woodbridge, Boydell \& Brewer), 151-69.

Gondek, M. (2003), 'Mapping Sculpture and Power: Symbolic Wealth in Early Medieval Scotland, 6th-11th Centuries AD', unpublished Ph.D. dissertation (University of Glasgow).

Hammond, M. (2005), 'A Prosopographical Analysis of Society in East Central Scotland, circa 1100 to 1260, with Special Reference to Ethnicity', unpublished Ph.D. dissertation (University of Glasgow).

Hammond, M. (2014), 'The Adoption and Routinization of Scottish Royal Charter Production for Lay Beneficiaries, 1124-1195', in D. Bates (ed.), Anglo-Norman Studies XXXVI, Proceedings of the Battle Conference 2013 (Woodbridge, Boydell \& Brewer), 91-115.

Harvey, P.D.A. (1992), 'Matthew Paris's Maps of Britain', in P.R. Coss \& S.D. Lloyd (eds), Thirteenth Century England IV (Woodbridge, Boydell \& Brewer), 109-21.

Haycock, M. (ed.) (2013), Prophecies from the Book of Taliesin (Aberystwyth, Cambrian Medieval Celtic Studies).

Henderson, I. (1998), 'Primus inter pares: the St Andrews Sarcophagus and Pictish Sculpture', in S. Foster (ed.), The St Andrews Sarcophagus: a Pictish Masterpiece and its International Connections, (Dublin 1998), 97-167.

Henderson, G. \& Henderson, I. (2004), The Arts of the Picts: Sculpture and Metalwork in Early Medieval Scotland (London, Thames \& Hudson).

Hennessey, W. (ed.) (1866), Chronicum Scotorum. A Chronicle of Irish Affairs from the Earliest Times to A.D. 1135, with a Supplement, Containing the Events from 1141 to 1150 (Rolls Series; London, Longmans, Green, Reader and Dyer).

Hennessey, W. \& MacCarthy, B. (eds) (1887-1901), Annala Uladh. Annals of Ulster. Otherwise Annala Senait: a Chronicle of Irish Affairs from A.D. 431 to A.D. 1540 (Dublin, HMSO).

Herbert, M. (1999), 'Sea-divided Gaels? Constructing Relationships between Irish and Scots c.800-1169', in B. Smith (ed.), Britain and Ireland 900-1300 (Cambridge, Cambridge University Press), 87-97.

Herbert, M. (2000), 'Rí Éirenn, Rí Alban: Kingship and Identity in the Ninth and Tenth centuries', in 
S. Taylor (ed.), Kings, Clerics and Chronicles 500-1297. Essays in honour of Marjorie Ogilvie Anderson on the occasion of her ninetieth birthday (Dublin, Four Courts Press), 62-72.

Howlett, R. (ed.) (1884-9), Chronicles of the Reigns of Stephen, Henry II and Richard I, 4 vols (Rolls Series; London, Longman).

Hudson, B. (1998), 'The Scottish Chronicle', Scottish Historical Review, 77: 129-61. http://dx.doi. org/10.3366/shr.1998.77.2.129

Hudson, J. (1996), The Formation of the English Common Law: Law and Society in England from the Norman Conquest to Magna Carta (London, Longman).

Hudson, J. (2003), 'Legal Aspects of Scottish Charter Diplomatic in the Twelfth Century: a Comparative Approach', in J. Gillingham (ed.), Anglo-Norman Studies XXV. Proceedings of the Battle Conference 2002 (Woodbridge, Boydell \& Brewer), 121-38.

Hudson, J. (2012), The Oxford History of the Laws of England, vol. 2, 871-1216 (Oxford, Oxford University Press). http://dx.doi.org/10.1093/acprof:oso/9780198260301.001.0001

Hutton, M. \& Peterson, W. (ed. and trans.) (1970), Tacitus Agricola, Germania, Dialogus, rev. R.M. Ogilvie et al. (London, Heinemann).

Innes, C. (ed.) (1842), Registrum de Dunfermelyn (Edinburgh, Bannatyne Club).

Innes, C. (ed.) (1849), Registrum Sancte Marie de Neubotle (Edinburgh, Bannatyne Club).

Innes, C. \& Chalmers, P. (eds) (1848), Liber Sancte Thome de Aberbrothoc, vol. i (Edinburgh, Bannatyne Club).

Jackson, K.H. (1954), ‘Two early Scottish names', Scottish Historical Review, 33: 14-18.

James, E. (2001), Britain in the First Millennium (London, Edward Arnold).

Mac Airt, S. \& Mac Niocaill, G. (eds) (1983), The Annals of Ulster (to A.D. 1131). Part I: Text and Translation (Dublin, Dublin Institute for Advanced Studies).

MacQueen, H. (1991), 'The Laws of Galloway: a Preliminary Survey', in R. Oram \& G. Stell (eds), Galloway: Land and Lordship (Edinburgh, Scottish Society for Northern Studies), 131-43.

MacQueen, J. \& MacQueen W. (eds) (1989), Scotichronicon by Walter Bower in Latin and English, gen. ed. D. Watt, vol. ii (Aberdeen, Aberdeen University Press).

McCarthy, D. (2008), The Irish Annals. Their Genesis, Evolution and History (Dublin, Four Courts Press).

Ní Mhaonaigh, M. (2004), 'Niall Noígíallach's Death-Tale', in Cín Chille Cúile: Texts, Saints and Places, Essays in Honour of Pádraig Ó Riain, in J. Carey, M. Herbert \& K. Murray (eds) (Aberystwyth, Celtic Studies Publications), 178-91.

Noble, G., Gondek, M., Campbell, E. \& Crook, M. (2013), 'Between Prehistory and History: the Archaeological Detection of Social Change among the Picts', Antiquity, 87: 1136-50. http://dx.doi.org/10.1017/S0003598X00049917

O’Brien, M.A. (ed.), Corpus Genealogiarum Hiberniae, with introduction by J.V. Kelleher (Dublin, Dublin Institute for Advanced Studies).

Oram, R. (1999), 'David I and the Conquest and Colonisation of Moray', Northern Scotland 19: 1-19. http://dx.doi.org/10.3366/nor.1999.0014

Oram, R. (2000), The Lordship of Galloway (Edinburgh, John Donald).

Ó Riain, P. (ed.) (1985), Corpus Genealogiarum Sanctorum Hiberniae (Dublin, Dublin Institute for Advanced Studies).

Parsons, E.J.S. (1958), The Map of Britain circa A.D. 1360 known as the Gough Map (Oxford, Bodleian Library).

Pryce, H. (2001), 'British or Welsh? National Identity in Twelfth-Century Wales', English Historical Review, 116: 775-801. http://dx.doi.org/10.1093/ehr/CXVI.468.775

Reynolds, S. (1997), Kingdoms and Communities in Western Europe 900-1300, 2nd edn (Oxford, Clarendon Press).

Shead, N. (2015), forthcoming, Scottish Episcopal Acta, vol. i, The Twelfth Century (Woodbridge, Scottish History Society/The Boydell Press). 
Shead, N., Stevenson, W. \& Watt, D. (eds) (1991), Scotichronicon by Walter Bower in Latin and English, vol. vi (Aberdeen, Aberdeen University Press).

Skene, W.F. (ed.) (1871), Johannis de Fordun Chronica Gentis Scotorum (Historians of Scotland; Edinburgh, David Douglas).

Stenton, D. (1953), 'Roger of Howeden and "Benedict”, English Historical Review, 68: 574-82. http://dx.doi.org/10.1093/ehr/LXVIII.CCLXIX.574

Stenton, D. (1965), English Justice between the Norman Conquest and the Great Charter, 1066-1215 (London, George Allen \& Unwin for the American Philosophical Society).

Stones, E.L.G. (1970), Anglo-Scottish Relations 1174-1328: Some Selected Documents, 2nd edn (Oxford, Clarendon Press).

Stringer, K.J. (1985), 'The Charters of David, Earl of Huntingdon and Lord of Garioch: a Study in Anglo-Scottish Diplomatic', in K.J. Stringer (ed.), Essays in the Nobility of Medieval Scotland (Edinburgh, John Donald), 72-101.

Stringer, K.J. (1999), 'Nobility and Identity in Medieval Britain and Ireland: the De Vesci Family, c.1120-1314', in B. Smith (ed.), Britain and Ireland 900-1300 (Cambridge, Cambridge University Press), 199-239.

Stringer, K.J. (2000), 'Acts of Lordship: the Records of the Lords of Galloway to 1234', in T. Brotherstone \& D. Ditchburn (eds), Freedom and Authority: Scotland c.1050-c.1650: Historical and Historiographical Essays Presented to Grant G. Simpson (East Linton, John Donald), 203-34.

Stringer, K.J. (2013), 'Aspects of the Norman Diaspora in Northern England and Southern Scotland', in K.J. Stringer \& A. Jotischky, Norman Expansion: Connections, Continuities and Contrasts (Farnham, Ashgate), 9-47.

Stubbs, W. (ed.) (1867), Gesta Regis Henrici Secundis Benedicti Abbatis, 2 vols (Rolls Series; London, Longman).

Stubbs, W. (ed.) (1868-71), Chronica Magistri Rogeri de Houedene, 4 vols (Rolls Series; London, Longman).

Stubbs, W. (ed.) (1876), Radulfi de Diceto Opera Omnia, 2 vols (Rolls Series; London, Longman).

Taylor, A. (2009), 'Leges Scocie and the Lawcodes of David I, William the Lion, and Alexander II', Scottish Historical Review, 88: 207-88. http://dx.doi.org/10.3366/E0036924109000869

Taylor, S. (2011), 'Pictish Place-Names Revisited', in S.T. Driscoll, J. Geddes \& M.A. Hall (eds), Pictish Progress. New Studies on Northern Britain in the Early Middle Ages (Leiden, Brill), 67-118.

Taylor, A. (2012), 'The Assizes of David I, King of Scots, 1124-53', Scottish Historical Review, 91: 197-238. http://dx.doi.org/10.3366/shr.2012.0100

Taylor, A. (2015), forthcoming, The Shape of the State in Medieval Scotland 1124-1290 (Oxford, Oxford University Press).

Taylor, S. \& Márkus, G. (2009), The Place-Names of Fife, vol. iii, St Andrews and the East Neuk (Donington, Shaun Tyas).

Thomas, C. (1994) And Shall Those Mute Stones Speak? Post-Roman Inscriptions in Western Britain (Cardiff, University of Wales Press).

Thomson, T. (1841), Liber Cartarum Prioratus Sancti Andree in Scotia (Edinburgh, Bannatyne Club).

Tierney, B. (1954), 'Some Recent Works on the Political Theories of the Medieval Canonists', Traditio, 10: $594-625$.

Ullmann, W. (1949), 'The Development of the Medieval Idea of Sovereignty', English Historical Review, 64: 1-33. http://dx.doi.org/10.1093/ehr/LXIV.CCL.1

Van Caenegem, R.C. (1990-1), English Lawsuits from William I to Richard I, 2 vols (London, Selden Society).

Van Hamel, A.G. (ed.) (1929), Labor Bretnach (Dublin, Irish Manuscripts Commission).

Warren, F.L. (1973), Henry II (London, Eyre Methuen).

Watson, W.J. (1926), The History of the Celtic Place-Names of Scotland (Edinburgh \& London, William Blackwood under the auspices of the Royal Celtic Society). 
Whitelock, D. (trans.) (1961), The Anglo-Saxon Chronicle. A Revised Translation, with D. Douglas \& S. Tucker (London, Eyre \& Spottiswoode).

Woolf, A. (2000), 'The "Moray Question" and the Kingship of Alba', Scottish Historical Review, 79: 145-64. http://dx.doi.org/10.3366/shr.2000.79.2.145

Woolf, A. (2006), 'Dún Nectain, Fortriu and the Geography of the Picts', Scottish Historical Review, 85 (2006): 182-201. http://dx.doi.org/10.1353/shr.2007.0029 http://dx.doi.org/10.3366/shr.2007.0029

Woolf, A. (2007), From Pictland to Alba, 789-1070 (New Edinburgh History of Scotland; Edinburgh, Edinburgh University Press).

Wormald, P. (1996), 'The Emergence of the Regnum Scottorum: a Carolingian Hegemony?', in Crawford, B. (ed.), Scotland in Dark Age Britain (St Andrews, St John's House), 131-60.

Young, A. (1993) 'The Earls and Earldom of Buchan in the Thirteenth Century', in A Grant \& and K.J. Stringer (eds), Medieval Scotland: Crown, Lordship and Community. Essays presented to G.W.S. Barrow (Edinburgh, Edinburgh University Press), 174-202.

The author: Dauvit Broun has taught Scottish history at the University of Glasgow since 1990 . He was appointed to the established chair in 2009. His research is chiefly on medieval Scottish identity and the contemporary dynamic of charters, chronicles and other non-literary texts and manuscripts. He is the author of The Irish Identity of the Kingdom of the Scots in the Twelfth and Thirteenth Centuries (Woodbridge, Boydell and Brewer: 1999); Scottish Independence and the Idea of Britain from the Picts to Alexander III (Edinburgh, Edinburgh University Press: 2007), and (with Julian Harrison), The Chronicle of Melrose Abbey. A Stratigraphic Edition. 3 vols. vol. i, Introduction and Facsimile Edition (Woodbridge, Scottish History Society/The Boydell Press).

Dauvit.Broun@glasgow.ac.uk

To cite the article: Dauvit Broun (2015), 'Britain and the beginning of Scotland', Journal of the British Academy, 3: 107-37.

DOI $10.85871 / \mathrm{jba} / 003.107$

This article is licensed under a

Creative Commons Attribution-NonCommercial-NoDerivs 3.0 Unported License.

Journal of the British Academy (ISSN 2052-7217) is published by

The British Academy - the national academy for the humanities and social sciences.

10-11 Carlton House Terrace, London, SW1Y 5AH

www.britishacademy.ac.uk 
